\title{
Prognostic significance of AMPK in human malignancies: A meta-analysis
}

\author{
Ji Cheng ${ }^{1}$, Xiaoming Shuai ${ }^{1}$, Jinbo Gao ${ }^{1}$, Ming Cai ${ }^{1}$, Guobin Wang ${ }^{1}$, Kaixiong Tao ${ }^{1}$ \\ ${ }^{1}$ Department of Gastrointestinal Surgery, Union Hospital, Tongji Medical College, Huazhong University of Science and \\ Technology, Wuhan, China
}

Correspondence to: Kaixiong Tao, email: kaixiongtaowhuh@126.com

Keywords: AMPK, prognosis, cancer, meta-analysis, malignancies

Received: May 23, $2016 \quad$ Accepted: September 20, 2016

Published: October 03, 2016

\section{ABSTRACT}

Background: AMPK is a well-investigated kinase mediating cellular metabolism and stress responses. However, its indicative role in survival prognosis remains illdefined. Therefore we performed this meta-analysis in order to clarify the prognostic impact of AMPK expression in human malignancies.

Methods: Literatures were retrieved via searching databases of PubMed, Web of Science, Embase and Cochrane Library. Studies comparing the prognostic significance between different AMPK levels among human malignancies were included into the pooled analysis. The statistical procedures were conducted by Review Manager 5.3 and the effect size was displayed by model of odds ratio. Subgroup analyses were additionally implemented to disclose the potential confounding elements. The outcome stability was examined by sensitivity analysis, and both Begg's test and Egger's test were utilized to detect the publication bias across the included studies.

Results: 21 retrospective cohorts were eventually obtained with a total samplesize of 9987 participants. Patients with higher AMPK expression had better outcomes of 3-year overall survival $(P<0.0001), 5$-year overall survival $(P<0.0001)$, 10-year overall survival $(P<0.0001), 3$-year disease free survival $(P<0.0001), 5$-year disease free survival $(P=0.002)$ and 10 -year disease free survival $(P=0.0004)$. Moreover, the majority of subgroup results also verified the favorably prognostic significance of AMPK over-expression. The outcome stability was confirmed by sensitivity analysis. Results of Begg's $(P=0.76)$ and Egger's test $(P=0.09)$ suggested that there was no publication bias within the included trials.

Conclusions: Higher expression of AMPK significantly indicates better prognosis in human malignancies.

\section{INTRODUCTION}

AMPK, short for AMP-activated kinase protein, serves as a highly conserved metabolic sensor in various tissue types. It is structurally constituted by a catalytic subunit $\alpha$ and two regulatory subunits $\beta$ and $\gamma$ in mammals [1]. Decreased level of cellular ATP or glucose deprivation could directly lead to activation of AMPK heterotrimer, which subsequently triggers downstream signaling cascade to enhance catabolic reactions and maintain energy homeostasis [2].

Due to its essential efficacy in metabolic modulation, potential role of AMPK in human tumorigenesis attracts numerous academic attentions. It is currently acknowledged that once activated, the AMPK complex involves in a variety of neoplastic pathways, functioning as a core tumor suppressor [3]. Along with the phosphorylation on AMPK $\alpha$, its downstream target COX-2 could be greatly depressed, which results in decreased level of inflammatory factors and carcinogenic risk $[4,5]$. On the other hand, activated AMPK is able to upregulate the expression of ULK1, which is a positive regulator of autophagy that protects the stressful cells from oncogenic accumulation [6,7]. Additionally, cellular senescence induced by activation of AMPK-p53 axis is another explanation of the tumor suppressor role of AMPK $[8,9]$. Thus based on such mechanisms, AMPK has been confirmed as a vital anti-tumor effector among multiple malignancies including hepatocellular carcinoma [10], colorectal cancer [11], lung cancer [12] and thyroid cancer [13], emerging as a potential therapeutic target in cancer treatment. 
However, despite of the accumulating laboratory evidences, the clinical significance of AMPK especially its prognostic role remains in controversy. Specifically, Zheng et al [14] reported that AMPK over-expression was correlated to a better prognosis among patients with hepatocellular carcinoma, while Baba et al [15] believed that the long-term survival of colorectal cancer was statistically irrelevant to AMPK expression levels. Since meta-analysis is a valuable tool to summarize conflicting literatures, we therefore performed this comprehensive meta-analysis in order to explain the prognostic significance of AMPK in human manlignancies and offer theoretical basis for future clinical applications.

\section{RESULTS}

\section{General characteristics}

Among the initially retrieved 3429 entries, 20 studies were eventually included into the meta-analysis, which totally consist of 21 retrospective cohorts (Figure 1).
The overall sample-size added up to 9987 participants, individually ranging from 42 to 3554 . China was the chief source region of included investigations $(n=7)$, followed by USA $(n=6)$. Liver cancer $(n=4)$, breast cancer $(n=3)$ and gastric cancer $(n=3)$ were the most frequent tumor types among included cohorts. The expression of AMPK was primarily detected by immunohistochemistry $(n=14)$, in addition to microarray $(n=3)$, polymerase chain reaction $(n=2)$ and western blot $(n=2)$. Data of mean-age and sex ratio were comparable among most cohorts, except for Kim 2013, Su 2014 and Zhang 2014-C2. More details of baseline characteristics were demonstrated in Table 1.

\section{Methodological assessment}

The majority of included trials were graded as highquality in methodology, including three 8-score studies, thirteen 7-score studies and three 6-score studies. Only Kim 2013 and Zhang 2014-C2 were appraised as lowquality cohorts, each with 5 scores by Newcastle-Ottawa Scale (Table 2).

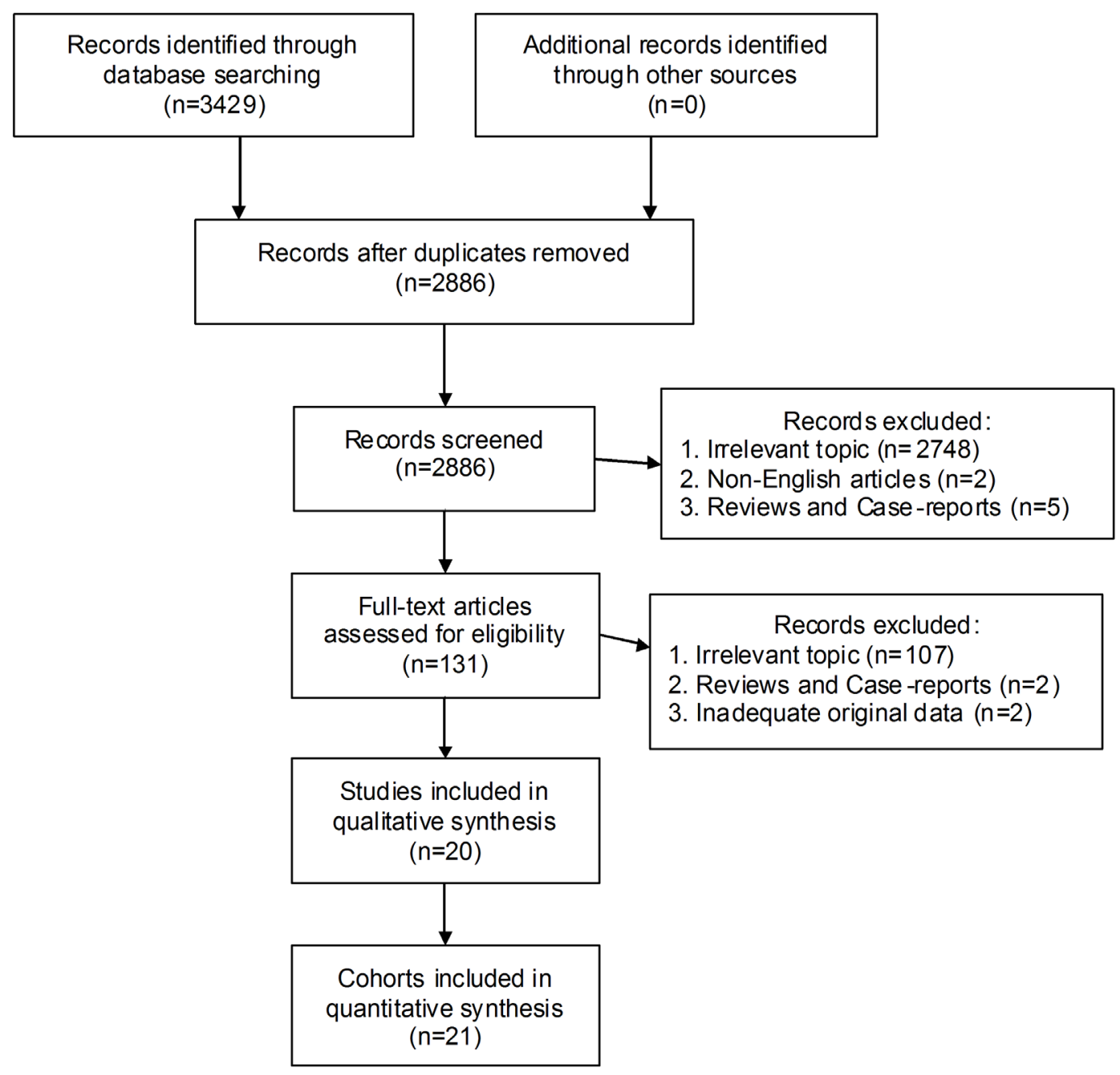

Figure 1: The selection flow chart of our pooled analysis. 
Table 1: Baseline characteristics of included studies

\begin{tabular}{|c|c|c|c|c|c|c|c|c|c|}
\hline Study & Country & Tumor type & $\begin{array}{c}\text { Detection } \\
\text { method }\end{array}$ & $\begin{array}{l}\text { p-AMPK } \\
\text { or АMPK }\end{array}$ & $\begin{array}{l}\text { TNM } \\
\text { stage }\end{array}$ & $\begin{array}{c}\text { AMPK } \\
\text { level }\end{array}$ & $\begin{array}{c}\text { Sample- } \\
\text { size } \\
\end{array}$ & Age & $\begin{array}{c}\text { Sex } \\
(\mathrm{M} / \mathrm{F}) \\
\end{array}$ \\
\hline \multirow[t]{2}{*}{$\begin{array}{l}\text { Baba } \\
2010[15]\end{array}$} & USA & $\begin{array}{c}\text { Colorectal } \\
\text { cancer }\end{array}$ & IHC & p-AMPK & I-IV & Low & 309 & NS & $99 / 210$ \\
\hline & & & & & & High & 409 & & $160 / 249$ \\
\hline \multirow[t]{2}{*}{$\begin{array}{l}\text { Bhandaru } \\
2014[16]\end{array}$} & Canada & Melanoma & IHC & AMPK & I-IV & Low & 50 & NS & $30 / 20$ \\
\hline & & & & & & High & 78 & & $52 / 26$ \\
\hline \multirow[t]{2}{*}{$\begin{array}{l}\text { Buckendahl } \\
2011[17]\end{array}$} & Germany & $\begin{array}{l}\text { Ovarian } \\
\text { cancer }\end{array}$ & $\mathrm{IHC}$ & AMPK & I-IV & Low & 31 & $56.4 \pm 13.3$ & $\begin{array}{c}\text { All } \\
\text { female }\end{array}$ \\
\hline & & & & & & High & 39 & & \\
\hline \multirow[t]{2}{*}{$\begin{array}{l}\text { Choi } \\
2015[18]\end{array}$} & USA & $\begin{array}{l}\text { Cervical } \\
\text { cancer }\end{array}$ & IHC & AMPK & I-II & Low & 51 & $42.1 \pm 12.0$ & $\begin{array}{c}\text { All } \\
\text { female }\end{array}$ \\
\hline & & & & & & High & 71 & & \\
\hline \multirow[t]{2}{*}{$\begin{array}{l}\text { Fodor } \\
2016[19]\end{array}$} & Hungary & Breast cancer & Microarray & AMPK & I-IV & Low & 1792 & NA & $\begin{array}{c}\text { All } \\
\text { female }\end{array}$ \\
\hline & & & & & & High & 1762 & & \\
\hline \multirow[t]{2}{*}{$\begin{array}{l}\text { Guo } \\
2015[20]\end{array}$} & USA & Lung cancer & IHC & p-AMPK & I-IV & Low & 72 & NA & NA \\
\hline & & & & & & High & 122 & & \\
\hline \multirow[t]{2}{*}{$\begin{array}{l}\text { Hoffman } \\
2013[21]\end{array}$} & USA & Lymphoma & Microarray & AMPK & I-IV & Low & 456 & 61.9 & $\begin{array}{c}\text { All } \\
\text { female }\end{array}$ \\
\hline & & & & & & High & 527 & 62.3 & \\
\hline \multirow[t]{2}{*}{$\begin{array}{l}\text { Kang } \\
2012[22]\end{array}$} & Korea & Gastric cancer & IHC & p-AMPK & II-IV & Low & 33 & $51.0 \pm 11.8$ & $14 / 19$ \\
\hline & & & & & & High & 40 & $60.0 \pm 8.0$ & $25 / 15$ \\
\hline \multirow[t]{2}{*}{$\begin{array}{l}\text { Kim } \\
2013[23]\end{array}$} & Korea & Gastric cancer & IHC & p-AMPK & I-IV & Low & 242 & $61.0 \pm 15.3$ & $140 / 102 *$ \\
\hline & & & & & & High & 379 & & $258 / 121 *$ \\
\hline \multirow[t]{2}{*}{ Lee 2012[24] } & China & Liver cancer & WB & AMPK & I-IV & Low & 19 & NA & $14 / 5$ \\
\hline & & & & & & High & 23 & & $19 / 4$ \\
\hline \multirow[t]{2}{*}{ Li 2012[25] } & China & $\begin{array}{l}\text { Ovarian } \\
\text { cancer }\end{array}$ & PCR & AMPK & I-IV & Low & 42 & NS & $\begin{array}{c}\text { All } \\
\text { female }\end{array}$ \\
\hline & & & & & & High & 34 & & \\
\hline \multirow[t]{2}{*}{$\mathrm{Su} 2014[26]$} & China & $\begin{array}{l}\text { Squamous cell } \\
\text { cancer of head } \\
\text { and neck }\end{array}$ & IHC & p-AMPK & I-IV & Low & 42 & $\mathrm{P}=\mathbf{0 . 0 2 *}$ & $39 / 3$ \\
\hline & & & & & & High & 76 & & $70 / 6$ \\
\hline \multirow[t]{2}{*}{$\begin{array}{l}\text { William } \\
\text { 2012[27] }\end{array}$} & USA & Lung cancer & Microarray & p-AMPK & I-IV & Low & 147 & $65.0 \pm 12.0$ & $77 / 70$ \\
\hline & & & & & & High & 316 & $66.0 \pm 14.5$ & $154 / 162$ \\
\hline Xie 2015[28] & USA & Glioma & PCR & AMPK & I-IV & $\begin{array}{l}\text { Low } \\
\text { High }\end{array}$ & $\begin{array}{l}124 \\
230\end{array}$ & NA & NA \\
\hline \multirow[t]{2}{*}{$\begin{array}{l}\text { Zhang 2014- } \\
\text { C1[29] }\end{array}$} & UK & Breast cancer & IHC & AMPK & I-III & Low & 80 & $56.0 \pm 9.8$ & $\begin{array}{c}\text { All } \\
\text { female }\end{array}$ \\
\hline & & & & & & High & 83 & & \\
\hline \multirow[t]{2}{*}{$\begin{array}{l}\text { Zhang 2014- } \\
\text { C2[29] }\end{array}$} & UK & Breast cancer & $\mathrm{IHC}$ & AMPK & I-III & Low & 162 & $54.0 \pm 13.5 *$ & $\begin{array}{c}\text { All } \\
\text { female }\end{array}$ \\
\hline & & & & & & High & 317 & & \\
\hline $\begin{array}{l}\text { Zhang } \\
2015[30]\end{array}$ & China & Liver cancer & WB & p-AMPK & I-IV & Low & 149 & NS & $121 / 105$ \\
\hline
\end{tabular}




\begin{tabular}{|c|c|c|c|c|c|c|c|c|c|}
\hline Study & Country & Tumor type & $\begin{array}{c}\begin{array}{c}\text { Detection } \\
\text { method }\end{array} \\
\end{array}$ & $\begin{array}{l}\text { p-AMPK } \\
\text { or AMPK } \\
\end{array}$ & $\begin{array}{l}\text { TNM } \\
\text { stage } \\
\end{array}$ & $\begin{array}{c}\begin{array}{c}\text { AMPK } \\
\text { level }\end{array} \\
\end{array}$ & $\begin{array}{c}\text { Sample- } \\
\text { size }\end{array}$ & Age & $\begin{array}{c}\text { Sex } \\
(\mathrm{M} / \mathbf{F}) \\
\end{array}$ \\
\hline \multirow{3}{*}{$\begin{array}{l}\text { Zheng } \\
2013[14]\end{array}$} & \multirow{3}{*}{ China } & \multirow{3}{*}{ Liver cancer } & \multirow{3}{*}{$\mathrm{IHC}$} & \multirow{3}{*}{ p-AMPK } & \multirow{3}{*}{ I-III } & High & 77 & & \\
\hline & & & & & & Low & 197 & NS & $165 / 32$ \\
\hline & & & & & & High & 76 & & $67 / 9$ \\
\hline \multirow[t]{2}{*}{$\begin{array}{l}\text { Zheng } \\
2016[31]\end{array}$} & \multirow[t]{2}{*}{ China } & \multirow[t]{2}{*}{ Liver cancer } & \multirow[t]{2}{*}{$\mathrm{IHC}$} & \multirow[t]{2}{*}{ p-AMPK } & \multirow[t]{2}{*}{ I-III } & Low & 145 & NA & $180 / 30$ \\
\hline & & & & & & High & 65 & & \\
\hline \multirow[t]{2}{*}{$\begin{array}{l}\text { ZhengZ } \\
2016[32]\end{array}$} & \multirow[t]{2}{*}{ China } & \multirow[t]{2}{*}{ Gastric cancer } & \multirow[t]{2}{*}{$\mathrm{IHC}$} & \multirow[t]{2}{*}{ p-AMPK } & \multirow[t]{2}{*}{ I-IV } & Low & 628 & NA & $757 / 315$ \\
\hline & & & & & & High & 444 & & \\
\hline \multirow[t]{2}{*}{$\begin{array}{l}\text { Zulato } \\
2014[33]\end{array}$} & \multirow[t]{2}{*}{ Italy } & \multirow[t]{2}{*}{$\begin{array}{l}\text { Colorectal } \\
\text { cancer }\end{array}$} & \multirow[t]{2}{*}{$\mathrm{IHC}$} & \multirow[t]{2}{*}{ p-AMPK } & \multirow[t]{2}{*}{ I-IV } & Low & 14 & $63.5 \pm 11.5$ & $8 / 6$ \\
\hline & & & & & & High & 34 & & $21 / 13$ \\
\hline
\end{tabular}

M/F: male/female; IHC: immunohistochemistry; NS: not significant; NA: not available; WB: western blot; PCR: polymerase chain reaction; $\mathrm{C} 1$ : cohort $1 ; \mathrm{C} 2$ : cohort 2 ; *: $\mathrm{P}<0.05$.

Table 2: Methodological assessment by Newcastle-Ottawa Scale

\begin{tabular}{|c|c|c|c|c|}
\hline Study & Selection & Comparability & Outcome & Total \\
\hline Baba 2010 & 3 & 1 & 3 & 7 \\
\hline Bhandaru 2014 & 3 & 2 & 2 & 7 \\
\hline Buckendahl 2011 & 3 & 2 & 3 & 8 \\
\hline Choi 2015 & 2 & 1 & 3 & 6 \\
\hline Fodor 2016 & 3 & 2 & 2 & 7 \\
\hline Guo 2015 & 3 & 2 & 2 & 7 \\
\hline Hoffman 2013 & 3 & 2 & 3 & 8 \\
\hline Kang 2012 & 2 & 2 & 3 & 7 \\
\hline Kim 2013 & 3 & 0 & 2 & 5 \\
\hline Lee 2012 & 3 & 2 & 2 & 7 \\
\hline Li 2012 & 3 & 2 & 2 & 7 \\
\hline Su 2014 & 3 & 1 & 3 & 7 \\
\hline William 2012 & 3 & 2 & 2 & 7 \\
\hline Xie 2015 & 3 & 2 & 2 & 7 \\
\hline Zhang 2014-C1 & 2 & 1 & 3 & 6 \\
\hline Zhang 2014-C2 & 2 & 1 & 2 & 5 \\
\hline Zhang 2015 & 3 & 2 & 2 & 7 \\
\hline Zheng 2013 & 2 & 1 & 3 & 6 \\
\hline Zheng 2016 & 2 & 2 & 3 & 7 \\
\hline ZhengZ 2016 & 3 & 1 & 3 & 7 \\
\hline Zulato 2014 & 3 & 2 & 3 & 8 \\
\hline
\end{tabular}




\section{Prognostic significance of AMPK in survival analysis}

3-year overall survival Compared with lower AMPK expression, patients featuring AMPK redundancy had significantly better outcome of 3-year overall survival $(\mathrm{P}<0.0001)$ (Figure 2).

5-year overall survival Our pooled analysis suggested that AMPK over-expression was a favorable indicator of 5-year overall survival among cancer suffers, in contrast to those with restricted levels $(\mathrm{P}<0.0001)$ (Figure 3).

10-year overall survival Patients with higher AMPK positivity were statistically correlated to better 10year survival outcome than those with limited expression $(\mathrm{P}<0.0001)$ (Figure 4).

3-year disease free survival Patients with overexpressed AMPK had superior outcome of 3-year disease free survival compared to those with lower expression $(\mathrm{P}<0.0001)$ (Supplementary Figure $\mathrm{S} 1$ ).

5-year disease free survival Higher AMPK expression predicted favorable results of 5-year disease free survival within cancer participants, in comparison to those with lower expression ( $\mathrm{P}=0.002)$ (Supplementary Figure S2).

10-year disease free survival In contrast to those with lower positivity, patients obtained better outcome of 10-year disease free survival in the presence of AMPK over-expression ( $\mathrm{P}=0.0004)$ (Supplementary Figure $\mathrm{S} 3$ ).

\section{Subgroup analyses}

\section{Tumor type}

3-year overall survival Higher AMPK level implicated a favorable 3-year overall survival among patients of gastric cancer $(\mathrm{P}=0.02)$, gynecological cancer $(\mathrm{P}=0.005)$, liver cancer $(\mathrm{P}<0.0001)$, lung cancer $(\mathrm{P}=0.0002)$ and other types $(\mathrm{P}=0.001)$. However, patients of breast cancer $(\mathrm{P}=0.20)$ and colorectal cancer $(\mathrm{P}=0.34)$ displayed similar prognosis regardless of different AMPK expressions (Supplementary Figure S4).

5-year overall survival AMPK over-expression was a beneficial indicator of 5 -year overall survival amid participants of breast cancer $(\mathrm{P}=0.03)$, gastric cancer $(\mathrm{P}=0.02)$, gynecological cancer $(\mathrm{P}=0.01)$, liver cancer $(\mathrm{P}<0.0001)$ and other types $(\mathrm{P}=0.0008)$. Nevertheless, irrespective of colorectal cancer $(\mathrm{P}=0.41)$ and lung cancer $(\mathrm{P}=0.18)$, there was no significant difference between both compared groups (Supplementary Figure S5).

\section{Sex ratio}

3-year overall survival Irrespective of womenspecific $(\mathrm{P}=0.006)$ or sex-unspecific study $(\mathrm{P}<0.0001)$,

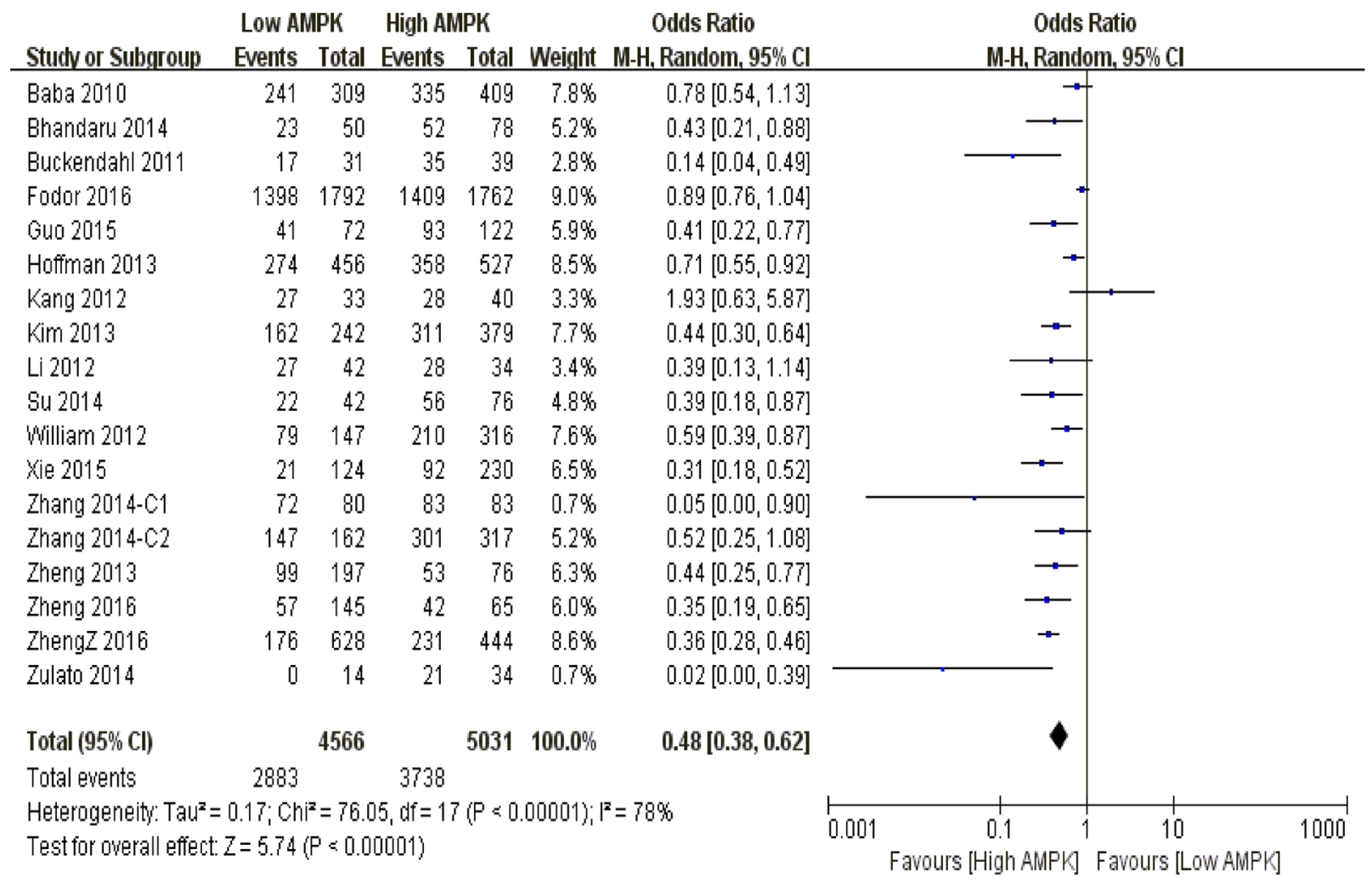

Figure 2: The correlation between AMPK expression levels and 3-year overall survival among cancer patients. 
higher AMPK expression was associated with better 3-year overall survival among cancer patients (Supplementary Figure S6).

5-year overall survival In contrast to lower AMPK positivity, over-expression of AMPK suggested a superior outcome of 5-year overall survival among patients from both women-specific study $(\mathrm{P}<0.0001)$ and sex-unspecific study $(\mathrm{P}<0.0001)$ (Supplementary Figure S7).

\section{Detection method}

3-year overall survival Irrespective of immunohistochemistry $(\mathrm{P}<0.0001)$, microarray $(\mathrm{P}=0.02)$ and polymerase chain reaction $(\mathrm{P}<0.0001)$, the overreactivity of AMPK was a potent predictor of better 3-year overall survival among cancer sufferers (Supplementary Figure S8).

5-year overall survival A better outcome of 5-year overall survival was observed among patients with higher level of AMPK expression, no matter it was detected by immunohistochemistry $(\mathrm{P}<0.0001)$, microarray $(\mathrm{P}<0.0001)$ or polymerase chain reaction $(\mathrm{P}=0.009)$ (Supplementary Figure S9).

\section{AMPK activation status}

3-year overall survival Higher expression of AMPK implied a favorable pooled outcome of 3-year overall survival among cancer patients, no matter in its normal $(\mathrm{P}=0.0002)$ or activated form $(\mathrm{P}<0.0001)$ (Supplementary Figure S10).

5-year overall survival Against lower expression level, a superior 5-year overall prognosis was obtained within patients featuring AMPK redundancy regardless of phosphorylated $(\mathrm{P}=0.0001)$ or original status $(\mathrm{P}<0.0001)$ (Supplementary Figure S11).

\section{TNM stage}

3-year overall survival Stronger AMPK positivity indicated longer 3-year overall survival among patients of I-IV $(\mathrm{P}<0.0001)$ and I-III $(\mathrm{P}<0.0001)$ stages. However, those with TNM II-IV stages had comparable survival outcome despite of different AMPK expression $(\mathrm{P}=0.25)$ (Supplementary Figure S12).

5-year overall survival Among participants with TNM I-IV $(\mathrm{P}<0.0001)$ and I-III $(\mathrm{P}<0.0001)$ stages, overexpression of AMPK was linked to better 5-year overall survival. Nevertheless, with regard to patients of II-IV stages, equivalent outcome of 5-year overall survival was obtained between lower and higher AMPK levels $(\mathrm{P}=0.56)$ (Supplementary Figure S13).

\section{Sensitivity analysis}

Firstly, by excluding low-quality trials of Kim 2013 and Zhang 2014-C2, results of 3-year overall survival

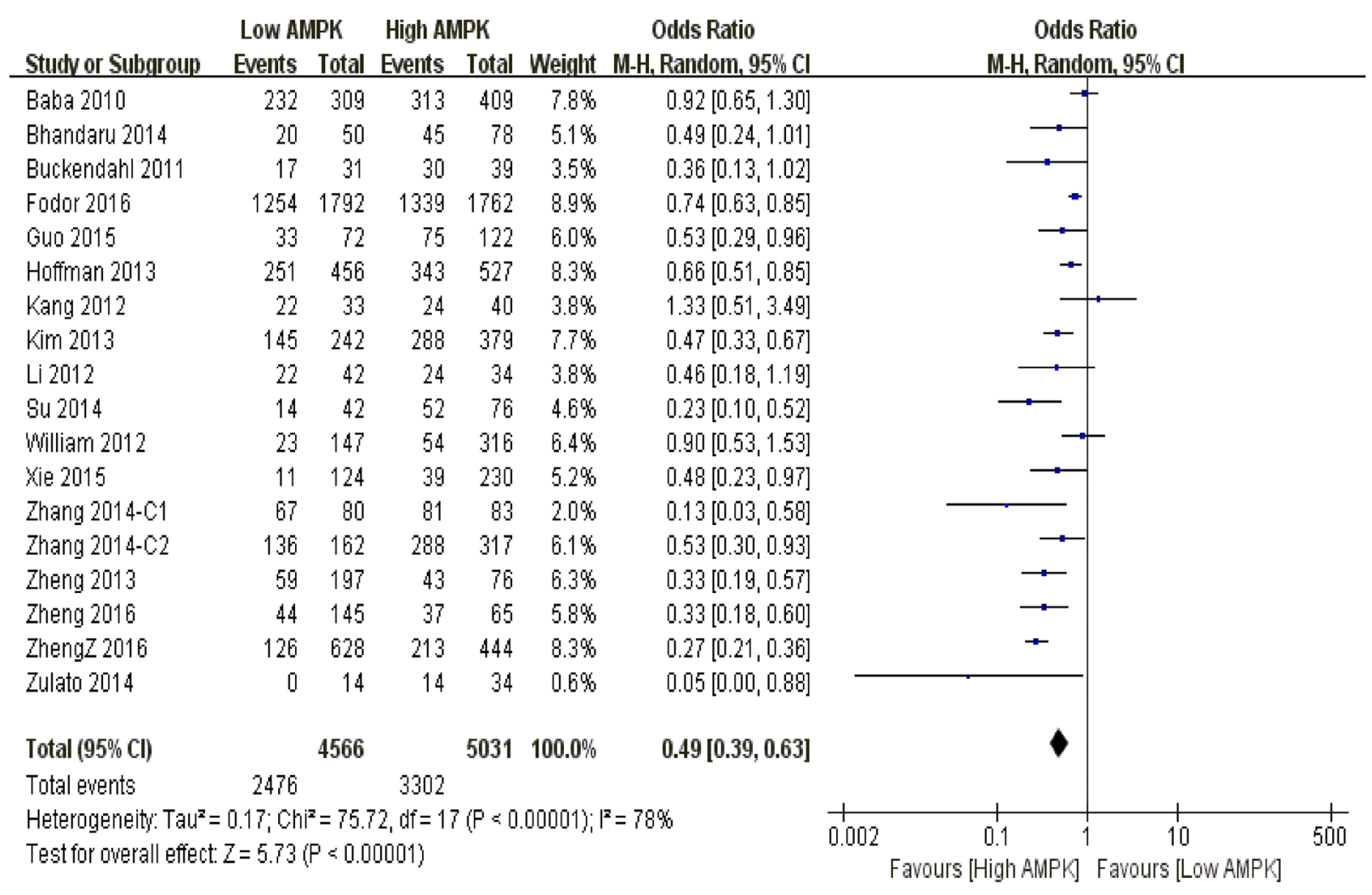

Figure 3: The correlation between AMPK expression levels and 5-year overall survival among cancer patients. 
( $\mathrm{P}<0.0001), 5$-year overall survival $(\mathrm{P}<0.0001), 10$-year overall survival $(\mathrm{P}=0.0005), 3$-year disease free survival $(\mathrm{P}<0.0001)$, 5-year disease free survival $(\mathrm{P}=0.03)$ and 10 year disease free survival $(\mathrm{P}=0.01)$ remained stable.

Secondly, by interchanging statistical modes between fixed-effects model and random-effects model, outcomes of 3 -year overall survival $(\mathrm{P}<0.0001), 5$-year overall survival $(\mathrm{P}<0.0001), 10$-year overall survival $(\mathrm{P}<0.0001)$, 3-year disease free survival $(\mathrm{P}<0.0001)$, 5 -year disease free survival $(\mathrm{P}<0.0001)$ and 10 -year disease free survival $(\mathrm{P}=0.0004)$ remained unchanged.

Thirdly, by randomly removing included trials on STATA 12.0 platform, the outcome stability of 3-year overall survival (Supplementary Figure S14), 5-year overall survival (Supplementary Figure S15), 10-year overall survival (Supplementary Figure S16), 3-year disease free survival (Supplementary Figure S17), 5-year disease free survival (Supplementary Figure S18) and 10year disease free survival (Supplementary Figure S19) was graphically confirmed.

\section{Publication bias}

Take 3-year overall survival for example, both results of Begg's test $(\mathrm{P}=0.76)$ (Supplementary Figure S20) and Egger's test $(\mathrm{P}=0.09)$ (Supplementary Figure $\mathrm{S} 21$ ) verified that there was no publication bias within the included cohorts.

\section{DISCUSSION}

According to our pooled results, higher expression of AMPK indicated better prognosis among cancer patients, irrespective of 3-year, 5-year, 10-year overall survival and disease free survival. This is the first conclusive evidence of the prognostic role of AMPK in human malignancies and the strength of the outcomes is quite persuasive since most of the $\mathrm{P}$ value is less than 0.00001 . These conclusions seem reasonable and comprehensible based on the present consensus that as a major tumor suppressor, AMPK activation restricts the metastatic tendency and malignant dissemination of the primary lesion [34], which accounts for almost 90 percents of cancer relevant mortality. Moreover, phosphorylated AMPK could effectively inhibit cell growth and induce apoptosis within neoplastic tissues [35], jointly contributing to the favorable survival outcome among patients with higher AMPK expression. However, deviating from the majority of included cohorts, Kang et al [22] suggested that inhibition of AMPK could successfully induce gastric cancer cell apoptosis so that patients with lower expression level were observed to have better overall survival. Since all participants from Kang's study were followed up after a cisplatin-based adjuvant chemotherapy, whether this is simply an exception or cisplatin-based chemotherapy has unspecific correlations with AMPK expression awaits further clarifications.

In addition, subgroup analyses provided more indepth perspectives of the AMPK significance. In terms of different tumor types, higher AMPK consistently served as an indicator of better prognosis among patients with gastric cancer, gynecological cancer, liver cancer and other kinds of cancer. On the other hand, its prognostic impact on the rest of malignancies remained ambiguous, especially for colorectal cancer. However, this outlier actually supports the experimental phenomenon by Baba et al [15] that AMPK signaling is only partially responsible for colorectal carcinogenesis and is activated merely in the setting of MAPK3/1 involvement. Since the positivity of MAPK3/1 is limited within colorectal cancer specimens, it is therefore explanatory that over-reactivity of AMPK is not a direct predictor of survival outcome among colorectal cancer patients. Besides, our pooled results confirmed that higher AMPK level revealed a better survival prognosis regardless of women-specific or sex-unspecific studies,

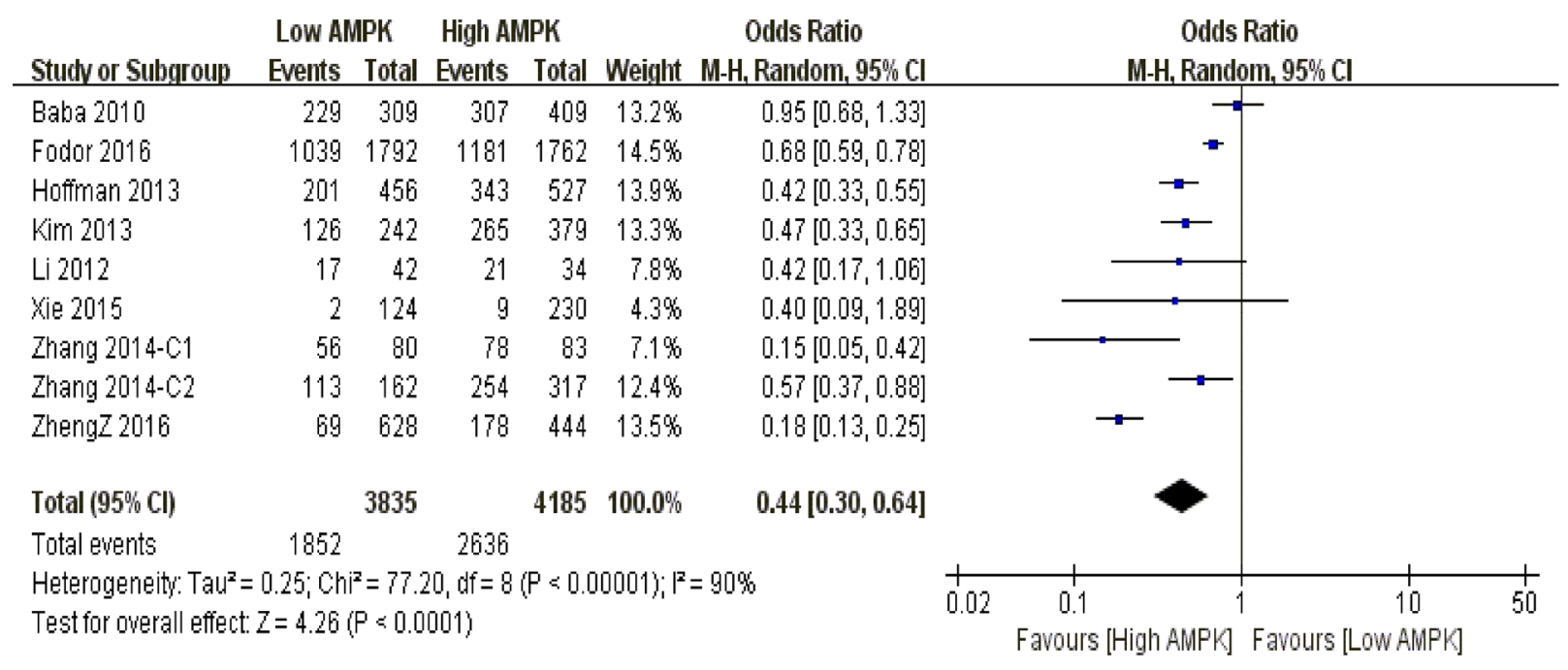

Figure 4: The correlation between AMPK expression levels and 10-year overall survival among cancer patients. 
ruling out the possibility of sex ratio as a confounding factor of internal heterogeneity. This pooled conclusion gives us a hint that AMPK may play a tumor suppressor role independent of estrogen and its downstream signaling among women-specific cancers, which calls for further mechanistic investigations. Moreover, irrespective of immunohistochemistry, microarray or polymerase chain reaction, higher AMPK expression was verified to positively correlate with survival expectancy of neoplastic sufferers. This result has confirmed the classical definition of AMPK that it bridges cellular molecules to construct an anti-tumor signaling network [36], since the upstream effectors could effectively trigger genomic transcription of AMPK before its downstream targets get stimulated. Thus more definite evidence is urgently required to explain the regulatory interplay between AMPK and the other essential factors. In terms of AMPK activation status, a favorable outcome of long-term survival was gained among patients with elevated AMPK expression, irrespective of phosphorylated or normal status. Since phosphorylated AMPK is actually the active form of AMPK, this result probably reveals that total AMPK expression is inductively increased along with the activating phosphorylation of AMPK, possibly mediated by self-stimulation of AMPK or its upstream kinase such as LKB1. What's more, the clinical TNM stage is commonly recognized as an interfering parameter of tumor prognosis. Nevertheless, we reported that the prognostic significance of AMPK over-expression was not distorted despite the disparity of TNM stages, which meant that AMPK may widely participate into various phases of tumorigenesis and cancer progression.

Besides the summary of pooled results, here we have an explanation of the usage of odds ratio as the effect-size model rather than hazard ratio. As we all known, survival analysis provides time-to-event data which hazard ratio fits best for. However, result of Cox regression is needed to transform Kaplan-Meier curves into hazard ratio, which is not available among most of current literatures. Furthermore, no matter how long the follow-up has lasted, there is merely one combined result deriving from the hazard ratio instead of the time-phased outcomes by odds ratio. Therefore we selected odds ratio as a statistical model as Ocana et al [37] and Badillo et al [38] recommended in Journal of the National Cancer Institute.

Although our meta-analysis was rigorously designed and performed, there were still some limitations. Firstly, all included cohorts were retrospectively analyzed, which might lead to poor internal comparability despite that the demographic characteristics were statistically comparable. Prospective and randomized trials are therefore needed to draw a more persuasive conclusion in future updates. Secondly, although the total sample-size nearly reached 10 thousands, the amount of included studies were still insufficient, especially for the subgroup analyses. Thirdly, despite that we had conducted enough subgroup analyses, the internal heterogeneity could not be fully eliminated, which hinted the existence of unclear confounding elements.
Taken together, this is the first meta-analysis which confirms that higher expression of AMPK is correlated to better prognosis of 3-year, 5-year, 10-year overall and disease free survival among cancer sufferers. Additionally, these prognostic tendencies are independent of tumor type, sex ratio, detection method, AMPK activation status and TNM stage. Therefore, we believe that AMPK targeted therapy is a promising and revolutionary strategy for cancer patients.

\section{MATERIALS AND METHODS}

All procedures mentioned below were performed in accord with PRISMA Checklist and Cochrane Collaboration protocols. Two investigators carried out each step independently, while any discrepancy was resolved by mutual discussion.

\section{Literature search}

Databases of PubMed, Web of Science, Embase and Cochrane Library were thoroughly examined using the search term "ampk AND (cancer OR carcinoma OR malignancy OR tumor)". Both abstract and full-text of the preliminary entries were screened in order to guarantee the eligibility of included studies.

\section{Selection criteria}

Studies that met the following criteria were eventually included: 1 . Formally published and Englishwritten articles until May 2016; 2. Studies that comparing the prognostic value of different AMPK expression in human malignancies;

Studies were eliminated due to the following reasons: 1. Overlapped or duplicated articles; 2. Inappropriate article type including reviews and casereports; 3 . Inadequate original data of survival analysis;

\section{Methodological assessment}

Since all of the eligible studies were observational cohorts, the Newcastle-Ottawa Scale was therefore utilized for methodological appraisal. There were totally three categories within the scale including selection, comparability and outcome, with a full-mark of nine. Studies were identified as high-quality in methodology with at least six scores.

\section{Data extraction}

A standardized form was designed for purpose of data extraction. Details of baseline characteristics (country; tumor type; detection method; AMPK activation status; TNM stage; groups; sample size; age; sex) were extracted from the main text or tables among the included documents. Survival data (3-year overall survival; 5-year overall survival; 10 - 
year overall survival; 3-year disease free survival; 5-year disease free survival; 10-year disease free survival;) was mainly obtained from Kaplan-Meier curves, with graphical assistance by Engauge Digitizer 4.1.

\section{Statistical analysis}

Review Manager 5.3 was employed as a statistical platform for pooled analysis. The effect size of each endpoint was presented by odds ratio and $95 \%$ confidence interval. $\mathrm{I}^{2}$ signified the degree of inconsistency across the included studies, whose value $<25 \%,<50 \%$ and $>50 \%$ implied low, moderate and severe heterogeneity respectively. Fixed-effects model was best-fit under circumstance of low heterogeneity, while random-effects model was the optimal choice for the remaining situations. Subgroup analyses were additionally conducted to seek for the potential confounding factors (tumor type; sex; detection method; AMPK activation status; TNM stage) within. By excluding low-quality trials and interchanging statistical modes, the stability of pooled outcomes was tested by sensitivity analysis. Moreover, Egger's test and Begg's test were applied to inspect publication bias among included trials. $\mathrm{P}<0.05$ denoted statistical significance between the comparison.

\section{ACKNOWLEDGMENTS}

We feel grateful to all staff in our department for offering methodological assistances.

\section{CONFLICTS OF INTEREST}

We declare that we have no conflicts of interest.

\section{GRANT SUPPORT}

This meta-analysis has been financially supported by Research Fund of Public Welfare in Health Industry, Health and Family Plan Committee of China (No.201402015) and National Natural Science Foundation of China (81572413).

\section{REFERENCES}

1. Li W, Saud SM, Young MR, Chen G, Hua B. Targeting AMPK for cancer prevention and treatment. Oncotarget. 2015; 6:7365-7378. doi: 10.18632/oncotarget.3629.

2. Jeon SM, Chandel NS, Hay N. AMPK regulates NADPH homeostasis to promote tumour cell survival during energy stress. Nature. 2012; 485:661-665.

3. Mihaylova MM, Shaw RJ. The AMPK signalling pathway coordinates cell growth, autophagy and metabolism. NAT Cell Biol. 2011; 13:1016-1023.

4. Lee YK, Park SY, Kim YM, Park OJ. Regulatory effect of the AMPK-COX-2 signaling pathway in curcumin-induced apoptosis in HT-29 colon cancer cells. Ann N Y Acad Sci. 2009; 1171:489-494.

5. Lee JY, Choi AY, Oh YT, Choe W, Yeo EJ, Ha J, Kang I. AMP-activated protein kinase mediates $\mathrm{T}$ cell activationinduced expression of FasL and COX-2 via protein kinase C theta-dependent pathway in human Jurkat $\mathrm{T}$ leukemia cells. Cell Signal. 2012; 24:1195-1207.

6. Kandadi MR, Hu N, Ren J. ULK1 plays a critical role in AMPK-mediated myocardial autophagy and contractile dysfunction following acute alcohol challenge. Curr Pharm Des. 2013; 19:4874-4887.

7. Mack HI, Zheng B, Asara JM, Thomas SM. AMPKdependent phosphorylation of ULK1 regulates ATG9 localization. Autophagy. 2012; 8:1197-1214.

8. Okoshi R, Ozaki T, Yamamoto H, Ando K, Koida N, Ono S, Koda T, Kamijo T, Nakagawara A, Kizaki H. Activation of AMP-activated protein kinase induces p53-dependent apoptotic cell death in response to energetic stress. J Biol Chem. 2008; 283:3979-3987.

9. Yi G, He Z, Zhou X, Xian L, Yuan T, Jia X, Hong J, He L, Liu J. Low concentration of metformin induces a p53dependent senescence in hepatoma cells via activation of the AMPK pathway. Int J Oncol. 2013; 43:1503-1510.

10. Cheng J, Huang T, Li Y, Guo Y, Zhu Y, Wang Q, Tan X, Chen W, Zhang Y, Cheng W, Yamamoto T, Jing X, Huang J. AMP-activated protein kinase suppresses the in vitro and in vivo proliferation of hepatocellular carcinoma. Plos One. 2014; 9:e93256.

11. Din FV, Valanciute A, Houde VP, Zibrova D, Green KA, Sakamoto K, Alessi DR, Dunlop MG. Aspirin inhibits mTOR signaling, activates AMP-activated protein kinase, and induces autophagy in colorectal cancer cells. Gastroenterology. 2012; 142:1504-1515.

12. Carretero J, Medina PP, Blanco R, Smit L, Tang M, Roncador G, Maestre L, Conde E, Lopez-Rios F, Clevers HC, Sanchez-Cespedes M. Dysfunctional AMPK activity, signalling through mTOR and survival in response to energetic stress in LKB1-deficient lung cancer. Oncogene. 2007; 26:1616-1625.

13. Cazarin JM, Coelho RG, Hecht F, Andrade BM, Carvalho DMD. 5 -AMP-activated Protein Kinase (AMPK) Regulates Papillary (TPC-1 and BCPAP) Thyroid Cancer Cell Survival, Migration, Invasion and Epithelial-toMesenchymal Transition. Thyroid. 2016.

14. Zheng L, Yang W, Wu F, Wang C, Yu L, Tang L, Qiu B, Li Y, Guo L, Wu M, Feng G, Zou D, Wang H. Prognostic significance of AMPK activation and therapeutic effects of metformin in hepatocellular carcinoma. Clin Cancer Res. 2013; 19:5372-5380.

15. Baba Y, Nosho K, Shima K, Meyerhardt JA, Chan AT, Engelman JA, Cantley LC, Loda M, Giovannucci E, Fuchs CS, Ogino S. Prognostic significance of AMPactivated protein kinase expression and modifying effect of MAPK3/1 in colorectal cancer. Br J Cancer. 2010; 103:1025-1033. 
16. Bhandaru M, Martinka M, Li G, Rotte A. Loss of AMPKalpha1 expression is associated with poor survival in melanoma patients. J Invest Dermatol. 2014; 134:1763-1766.

17. Buckendahl AC, Budczies J, Fiehn O, Darb-Esfahani S, Kind T, Noske A, Weichert W, Sehouli J, Braicu E, Dietel M, Denkert C. Prognostic impact of AMP-activated protein kinase expression in ovarian carcinoma: correlation of protein expression and GC/TOF-MS-based metabolomics. Oncol Rep. 2011; 25:1005-1012.

18. Choi CH, Chung JY, Cho H, Kitano H, Chang E, Ylaya K, Chung EJ, Kim JH, Hewitt SM. Prognostic Significance of AMP-Dependent Kinase Alpha Expression in Cervical Cancer. Pathobiology. 2015; 82:203-211.

19. Fodor T, Szanto M, Abdul-Rahman O, Nagy L, Der A, Kiss B, Bai P. Combined Treatment of MCF-7 Cells with AICAR and Methotrexate, Arrests Cell Cycle and Reverses Warburg Metabolism through AMP-Activated Protein Kinase (AMPK) and FOXO1. Plos One. 2016; 11:e150232.

20. Guo C, Hao C, Shao R, Fang B, Correa AM, Hofstetter WL, Roth JA, Behrens C, Kalhor N, Wistuba II, Swisher SG, Pataer A. RNA-dependent protein kinase (PKR) depletes nutrients, inducing phosphorylation of AMP-activated kinase in lung cancer. Oncotarget. 2015; 6:11114-11124. doi: 10.18632/oncotarget.3573.

21. Hoffman AE, Demanelis $\mathrm{K}, \mathrm{Fu} \mathrm{A}$, Zheng T, Zhu Y. Association of AMP-activated protein kinase with risk and progression of non-Hodgkin lymphoma. Cancer Epidemiol Biomarkers Prev. 2013; 22:736-744.

22. Kang BW, Jeong JY, Chae YS, Lee SJ, Lee YJ, Choi JY, Lee IK, Jeon SW, Bae HI, Lee DK, Kwon OK, Chung HY, Yu W, Kim JG. Phosphorylated AMP-activated protein kinase expression associated with prognosis for patients with gastric cancer treated with cisplatin-based adjuvant chemotherapy. Cancer Chemother Pharmacol. 2012; 70:735-741.

23. Kim JG, Lee SJ, Chae YS, Kang BW, Lee YJ, Oh SY, Kim $\mathrm{MC}$, Kim KH, Kim SJ. Association between phosphorylated AMP-activated protein kinase and MAPK3/1 expression and prognosis for patients with gastric cancer. OncologyBasel. 2013; 85:78-85.

24. Lee CW, Wong LL, Tse EY, Liu HF, Leong VY, Lee JM, Hardie DG, Ng IO, Ching YP. AMPK promotes p53 acetylation via phosphorylation and inactivation of SIRT1 in liver cancer cells. CANCER RES. 2012; 72:4394-4404.

25. Li C, Liu VW, Chiu PM, Chan DW, Ngan HY. Overexpressions of AMPK subunits in ovarian carcinomas with significant clinical implications. Bmc Cancer. 2012; 12:357.

26. Su YW, Lin YH, Pai MH, Lo AC, Lee YC, Fang IC, Lin J, Hsieh RK, Chang YF, Chen CL. Association between phosphorylated AMP-activated protein kinase and acetylCoA carboxylase expression and outcome in patients with squamous cell carcinoma of the head and neck. Plos One. 2014; 9:e96183.
27. William WN, Kim JS, Liu DD, Solis L, Behrens C, Lee JJ, Lippman SM, Kim ES, Hong WK, Wistuba II, Lee HY. The impact of phosphorylated AMP-activated protein kinase expression on lung cancer survival. ANN ONCOL. 2012; 23:78-85.

28. Xie Q, Wu Q, Horbinski CM, Flavahan WA, Yang K, Zhou W, Dombrowski SM, Huang Z, Fang X, Shi Y, Ferguson AN, Kashatus DF, Bao S, Rich JN. Mitochondrial control by DRP1 in brain tumor initiating cells. Nat Neurosci. 2015; 18:501-510.

29. Zhang Y, Storr SJ, Johnson K, Green AR, Rakha EA, Ellis IO, Morgan DA, Martin SG. Involvement of metformin and AMPK in the radioresponse and prognosis of luminal versus basal-like breast cancer treated with radiotherapy. Oncotarget. 2014; 5:12936-12949. doi: 10.18632/oncotarget.2683.

30. Zhang ZY, Hong D, Nam SH, Kim JM, Paik YH, Joh JW, Kwon CH, Park JB, Choi GS, Jang KY, Park CK, Kim SJ. SIRT1 regulates oncogenesis via a mutant p53-dependent pathway in hepatocellular carcinoma. J Hepatol. 2015; 62:121-130.

31. Zheng LY, Wu L, Lu J, Zou DJ, Huang Q. Expression of Phosphorylated AMP-Activated Protein Kinase Predicts Response to Transarterial Chemoembolization in Postoperative Cases of Hepatocellular Carcinoma. Medicine (Baltimore). 2016; 95:e2908.

32. Zheng Z, Zheng Y, Zhang M, Wang J, Yu G, Fang W. Reciprocal expression of $\mathrm{p}$-AMPKa and p-S6 is strongly associated with the prognosis of gastric cancer. Tumour Biol. 2016; 37:4803-4811.

33. Zulato E, Bergamo F, De Paoli A, Griguolo G, Esposito G, De Salvo GL, Mescoli C, Rugge M, Nardin M, Di Grazia L, Lonardi S, Indraccolo S, Zagonel V. Prognostic significance of AMPK activation in advanced stage colorectal cancer treated with chemotherapy plus bevacizumab. Br J Cancer. 2014; 111:25-32.

34. Li N, Huang D, Lu N, Luo L. Role of the LKB1/AMPK pathway in tumor invasion and metastasis of cancer cells (Review). Oncol Rep. 2015; 34:2821-2826.

35. Sanduja S, Feng Y, Mathis RA, Sokol ES, Reinhardt F, Halaban R, Gupta PB. AMPK promotes tolerance to Ras pathway inhibition by activating autophagy. Oncogene. 2016.

36. Faubert B, Vincent EE, Poffenberger MC, Jones RG. The AMP-activated protein kinase (AMPK) and cancer: many faces of a metabolic regulator. Cancer Lett. 2015; 356:165-170.

37. Ocana A, Vera-Badillo F, Seruga B, Templeton A, Pandiella A, Amir E. HER3 overexpression and survival in solid tumors: a meta-analysis. J Natl Cancer Inst. 2013; 105:266-273.

38. Vera-Badillo FE, Templeton AJ, de Gouveia P, Diaz-Padilla I, Bedard PL, Al-Mubarak M, Seruga B, Tannock IF, Ocana A, Amir E. Androgen receptor expression and outcomes in early breast cancer: a systematic review and meta-analysis. J Natl Cancer Inst. 2014; 106:t319. 